\title{
NOR Polymorphism and Chromosome Analysis of Banggai Cardinalfish, Pterapogon kauderni (Perciformes, Apogonidae)
}

\author{
Wannapa Kasiroek ${ }^{1,2}$, Chantra Indananda ${ }^{3}$, Krit Pinthong ${ }^{4}$, \\ Weerayuth Supiwong ${ }^{5}$, Puan Pengseng ${ }^{6}$ and Alongklod Tanomtong ${ }^{7 *}$ \\ ${ }^{1}$ Department of Aquatic Science, Faculty of Science, Burapha University, Muang, Chonburi 20131, Thailand \\ ${ }^{2}$ Institute of Marine Science, Burapha University, Muang, Chonburi 20131, Thailand \\ ${ }^{3}$ Department of Biology, Faculty of Science, Burapha University, Muang, Chonburi 20131, Thailand \\ ${ }^{4}$ Department of Fundamental Science, Faculty of Science and Technology, Surindra Rajabhat University, \\ Muang, Surin 32000, Thailand \\ ${ }^{5}$ Faculty of Applied Science and Engineering, Khon Kaen University, \\ Nong Kai Campus, Muang, Nong Kai 43000, Thailand \\ ${ }^{6}$ School of Agricultural of Technology, Walailak University, Thasala, Nakhon Si Thammarat 80160, Thailand \\ ${ }^{7}$ Toxic Substances in Livestock and Aquatic Animals Research Group, Department of Biology, Faculty of Science, \\ Khon Kaen University, Muang, Khon Kaen 40002, Thailand
}

Received December 26, 2014; accepted March 23, 2015

\begin{abstract}
Summary This is the first nucleolar organizer region (NOR) polymorphism and chromosome analysis of Banggai cardinalfish (Pterapogon kauderni Koumans, 1933). Kidney cell samples were taken from 10 male and 10 female fish. Mitotic chromosome preparations were prepared directly from kidney cells. Conventional and AgNOR banding techniques were applied to stain the chromosomes. The results showed that the diploid chromosome number of $P$. kauderni was $2 n=46$, and the fundamental number (NF) was 92 in both males and females. The types of chromosomes were 6 large acrocentric, 4 medium metacentric, 14 medium submetacentric, and 22 medium acrocentric chromosomes. The results indicated that the short arm subtelomeric of the acrocentric chromosome pair 13 showed clearly observable NORs. This finding exhibited that three NOR polymorphism patterns were found: 1) homomorphic which shows an equal size of both chromosome pair 13 (13a13a), 2) heteromorphic that displays different sizes of NORs of chromosome pair 13 (13a13c) and 3) heteromorphic which is found in only one homologous chromosome pair 13 (13a13b). There was no observation of strange size chromosomes related to sex. The karyotype formula for P. kauderni was:
\end{abstract}

$2 n$ (diploid) $46=\mathrm{L}_{6}^{\mathrm{a}}+\mathrm{M}_{4}^{\mathrm{m}}+\mathrm{M}_{14}^{\mathrm{sm}}+\mathrm{M}_{22}^{\mathrm{a}}$

Key words Pterapogon kauderni, Chromosome, NOR polymorphism, Karyotype.

The Banggai cardinalfish (Pterapogon kauderni Koumans, 1933) (Fig. 1) belongs to the class Actinopterygii (ray-finned fishes), superorder Percomorpha, order Perciformes, suborder Percoidei, and family Apogonidae (Nelson 2006). Cardinalfishes are a family Apogonidae found in the Atlantic, Indian, and Pacific Oceans; they are chiefly marine, but some species are found in brackish water and a few are found in fresh water. A handful of species are kept in the aquarium and are popular as small, peaceful, and colorful fish. Most species live in tropical or subtropical waters, where they inhabit coral reefs and lagoons (Johnson and Gill 1998, Kasiroek et al. 2017).

Nucleolar organizer regions (NORs) are parts of chromosomes in which there are ribosomal ribonucleic acid (rRNA) encoding genes (5.8S, 18S, and 28S). In all

\footnotetext{
* Corresponding author, e-mail: tanomtong@hotmail.com DOI: $10.1508 /$ cytologia. 82.17
}

eukaryotic organisms, rRNA genes occur in many copies, thus reflecting high cell demand for rRNA. NORs, as ribosomal gene clusters that were active in previous interphase, form prominent cytogenetic features, namely secondary constrictions (Andraszek et al. 2009). An important characteristic of NORs in fish is its inter- and intra-species polymorphism. NOR characterization can be a cytogenetic marker for cytotaxonomic studies and can even aid in constructing phylogenetic hypotheses for several fish groups. Some fish groups present a simple NOR system characterized by ribosomal cistrons on only one chromosome pair, whereas others have multiple NOR systems composed of cistrons dispersed over several chromosomes (Galetti 1998).

Although basic cytogenetic information is available for Apogonidae (Table 1), little is known about the karyotypic features of apogonids in the Pacific. The present study is the first report on chromosomal char- 


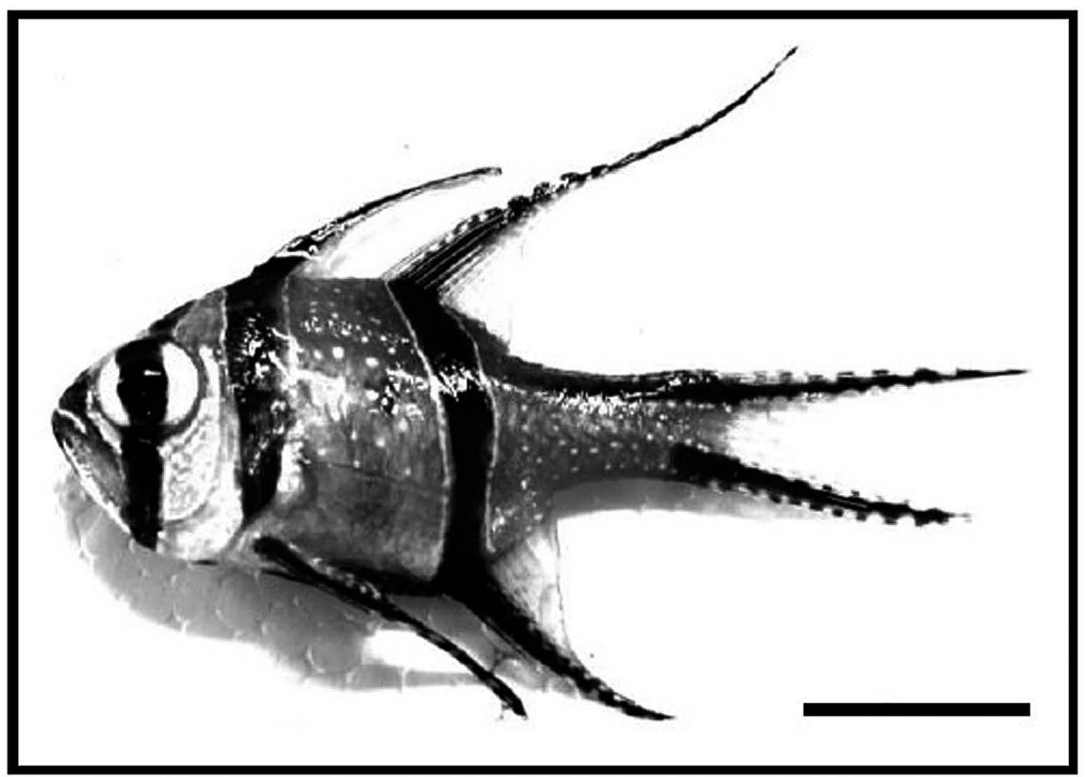

Fig. 1. General characteristic of the Banggai cardinalfish, Pterapogon kauderni Koumans, 1933 (Perciformes: Apogonidae). Scale bar indicates $2 \mathrm{~cm}$.

Table 1. Review of fish cytogenetic reports in the family Apogonidae (genera; Apogon, Nectamia, Phaeoptyx, Pterapogon, and Sphaeramia).

\begin{tabular}{|c|c|c|c|c|c|c|}
\hline Species & $2 n$ & NF & Karyotype & Ag-NORs & Locality & Reference \\
\hline Apogon americanus & 36 & 70 & $12 m+6 s m+16 a+2 t$ & 2 (TR) & Brazil & Araújo et al. (2010) \\
\hline \multirow[t]{3}{*}{ A. binotatus } & 36 & 50 & $14 \mathrm{~m} / \mathrm{sm}+22 \mathrm{a} / \mathrm{t}$ & - & USA & Rivlin et al. (1987) \\
\hline & 36 & 62 & $26 \mathrm{~m} / \mathrm{sm}+10 \mathrm{a} / \mathrm{t}$ & - & USA & Rivlin et al. (1987) \\
\hline & 35 & 49 & $14 \mathrm{~m} / \mathrm{sm}+21 \mathrm{a} / \mathrm{t}$ & - & USA & Rivlin et al. (1987) \\
\hline A. doederleini & 46 & 54 & $2 m+6 s m+38 a / t$ & - & Japan & Ojima and Kojima (1985) \\
\hline \multirow[t]{2}{*}{ A. endekataenia } & 46 & 46 & $46 a / t$ & - & India & Rishi (1973) \\
\hline & 46 & 52 & $2 m+4 s m+16 a+24 t$ & - & Japan & Murofushi (1986) \\
\hline A. imberbis & 36 & 56 & - & - & Spain & Alvarez et al. (1991) \\
\hline A. lineatus & 46 & 52 & $2 m+4 s m+2 a+38 t$ & - & Japan & Murofushi (1986) \\
\hline A. maculatus & 34 & 61 & $27 \mathrm{~m} / \mathrm{sm}+7 \mathrm{a} / \mathrm{t}$ & - & Puerto Rico & Rivlin et al. (1988) \\
\hline A. moluccensis & 46 & 46 & $46 \mathrm{a} / \mathrm{t}$ & - & India & Rishi (1973) \\
\hline \multirow[t]{4}{*}{ A. notatus } & 46 & 52 & $2 \mathrm{~m}+4 \mathrm{sm}+40 \mathrm{a} / \mathrm{t}$ & - & Japan & Ojima and Kojima (1985) \\
\hline & 46 & 53 & $2 m+5 s m+39 a / t$ & - & Japan & Ojima and Kojima (1985) \\
\hline & 46 & 52 & $2 m+4 s m+40 a / t$ & - & Japan & Ojima and Kojima (1985) \\
\hline & 46 & 52 & $2 m+4 s m+40 a / t$ & & Japan & Murofushi (1986) \\
\hline A. nubilis & 46 & 92 & $2 m+36 s m+8 a$ & - & USA & Rivlin et al. (1986) \\
\hline A. pseudomaculatus & 36 & 66 & $30 \mathrm{~m} / \mathrm{sm}+2 \mathrm{a}+4 \mathrm{t}$ & - & Puerto Rico & Rivlin et al. (1986) \\
\hline \multirow[t]{2}{*}{ A. semilineatus } & 46 & 52 & $2 m+4 s m+20 a+20 t$ & - & Japan & Murofushi et al. (1980) \\
\hline & 46 & 54 & $2 \mathrm{~m}+6 \mathrm{sm}+38 \mathrm{a} / \mathrm{t}$ & - & Japan & Ojima and Kojima (1985) \\
\hline Nectamia fusca & 46 & - & $2 \mathrm{~m}+44 \mathrm{sm} / \mathrm{a} / \mathrm{t}$ & - & Pacific & Rivlin et al. (1986) \\
\hline Phaeoptyx pigmentaria & 38 & - & $6 \mathrm{~m}+32 \mathrm{sm} / \mathrm{a} / \mathrm{t}$ & - & Atlantic & Rivlin et al. (1986) \\
\hline Pterapogon kauderni & 46 & 92 & $4 m+14 s m+28 a$ & $2(\mathrm{TR})$ & Thailand & Present study \\
\hline Sphaeramia orbicularis & 46 & 50 & $4 \mathrm{sm}+42 \mathrm{a} / \mathrm{t}$ & - & Pacific & Ojima and Kojima (1985) \\
\hline
\end{tabular}

Remarks: $2 n=$ diploid chromosome number, $\mathrm{NF}=$ fundamental number (number of chromosome arm), $\mathrm{m}=\mathrm{metacentric}, \mathrm{sm}=\mathrm{submetacentric}$, $\mathrm{a}=$ acrocentric, $\mathrm{t}=$ telocentric chromosome, $\mathrm{NORs}=$ nucleolar organizer regions, $\mathrm{TR}=$ subtelomeric region, and $-=$ not available.

acteristics of $P$. kauderni using conventional staining and Ag-NOR banding techniques. The results obtained will increase our basic knowledge of the cytogenetics of P. kauderni, which could form the basis for future research and provide data to ensure their survival.

\section{Materials and methods}

\section{Sample collection}

Twenty $P$. kauderni individuals (10 males and $10 \mathrm{fe}$ - males) were collected from Phang Nga Coastal Research and Development Center, Thailand. All specimens were maintained in aerated, flowing seawater aquaria until analysis.

\section{Chromosome preparation}

Chromosomes were prepared in vivo (Nanda et al. 1995) as follows. Phytohemagglutinin (PHA) solution was injected into the fish's abdominal cavity. After $24 \mathrm{~h}$, colchicine was injected into the fish's intramuscular 
and/or its abdominal cavity and then left for $2-4 \mathrm{~h}$. The kidney was cut into small pieces, and then squash mixed with $0.075 \mathrm{M} \mathrm{KCl}$ (Kasiroek et al. 2017). After discarding all large pieces of tissue, $8 \mathrm{~mL}$ of cell sediments were transferred to a centrifuge tube and incubated for 25$35 \mathrm{~min}$. The $\mathrm{KCl}$ was discarded from the supernatant after centrifugation at $1200 \mathrm{rpm}$ for $8 \mathrm{~min}$. Cells were fixed in fresh, cool fixative (3 methanol: 1 glacial acetic acid) to which up to $8 \mathrm{~mL}$ of fixative were gradually added before being centrifuged again at $1200 \mathrm{rpm}$ for $8 \mathrm{~min}$, at which time the supernatant was discarded. The fixation was repeated until the supernatant was clear, and the pellet was mixed with $1 \mathrm{~mL}$ of fixative. The mixture was dropped onto a clean and cold slide by a micropipette, and then an air-drying technique was applied.

\section{Chromosome staining}

Conventional staining was done using 20\% Giemsa's solution for $30 \mathrm{~min}$ (Chooseangjaew et al. 2017). AgNOR banding technique was performed by adding four drops of $50 \%$ silver nitrate and $2 \%$ gelatin on slides. The slides were then sealed with cover glasses and incubated at $60^{\circ} \mathrm{C}$ for $5 \mathrm{~min}$. Next, the slides were soaked in distilled water until the cover glasses were separated. Then, they were stained with $20 \%$ Giemsa's solution for $1 \mathrm{~min}$ (Howell and Black 1980, Sangpakdee et al. 2017).

\section{Results and discussion}

Diploid chromosome number, fundamental number and karyotype of $\mathrm{P}$. kauderni

According to the results, this is the first report on $P$. kauderni cytogenetical knowledge. The present investigation revealed that the somatic chromosome number of P. kauderni is $2 n=46$, the fundamental numbers (NF) were 92 in both males and females (Fig. 2). The types of chromosomes were 6 large acrocentric, 4 medium metacentric, 14 medium submetacentric, and 22 medium acrocentric chromosomes. Comparative studies with others in family Apogonidae have shown the same chromosome number as those found in Apogon doederleini, A. notatus, Sphaeramia orbicularis (Ojima and Kojima 1985), A. endekataenia (Rishi 1973), A. lineatus (Murofushi 1986), A. moluccensis (Rishi 1973), A. semilineatus (Murofushi et al. 1980, Ojima and Kojima 1985), and Nectamia fusca (Rivlin et al. 1986). Similar to other species in family Apogonidae, no cytologically distinguishable sex chromosome was observed (Araújo et al. 2010).

According to the previous cytogenetic information of the family Apogonidae, it is known that it has particular cytogenetic features, as they present extremely low diploid values in relation to the order Perciformes, and
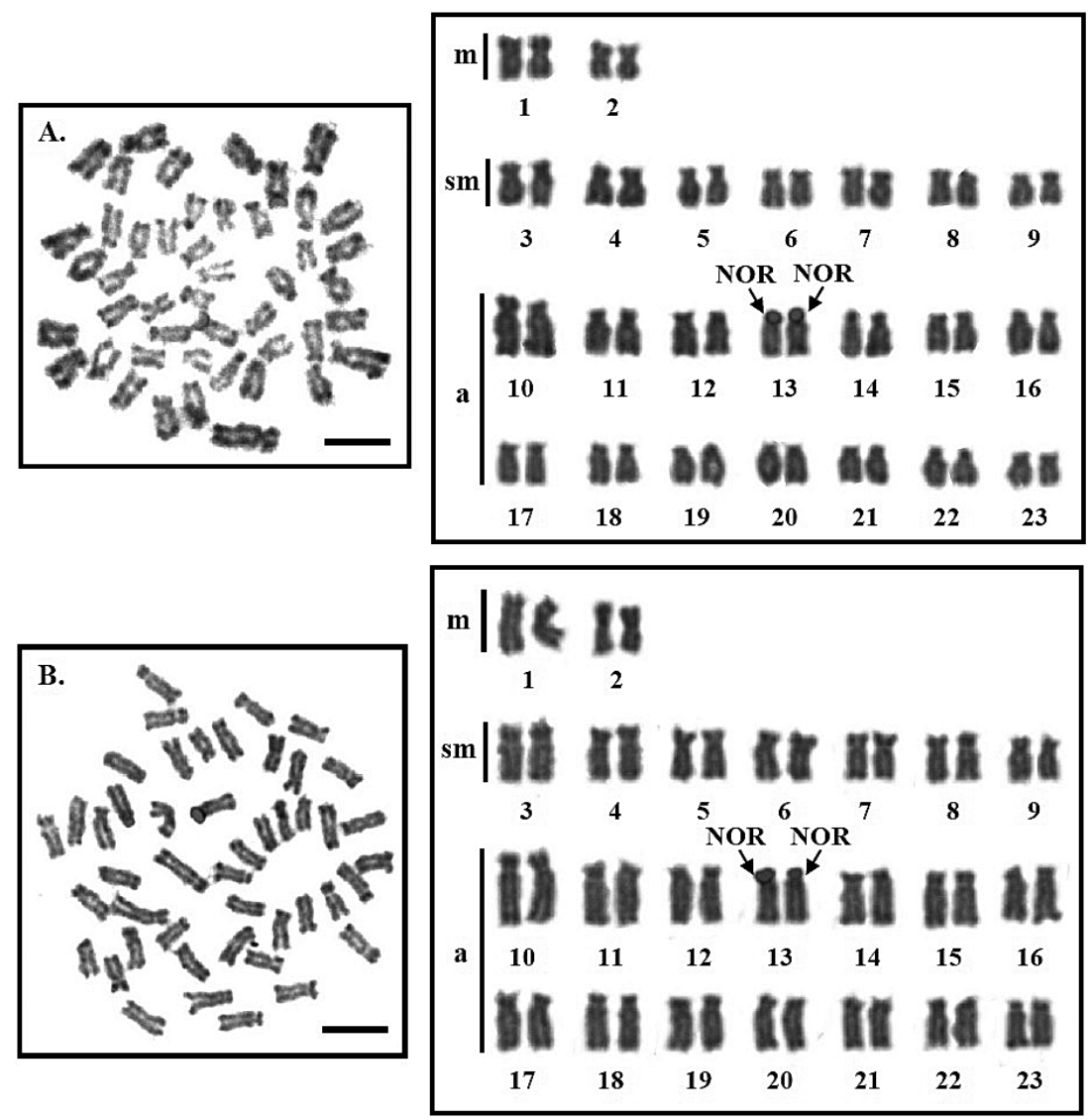

Fig. 2. Metaphase chromosome plates and karyotypes of the Banggai cardinalfish (Pterapogon kauderni) male (A) and female (B), $2 n$ (diploid) $=46$ by conventional staining technique. Arrows indicates nucleolar organizer regions (NORs) (Scale bar $=5 \mu \mathrm{m})$. 

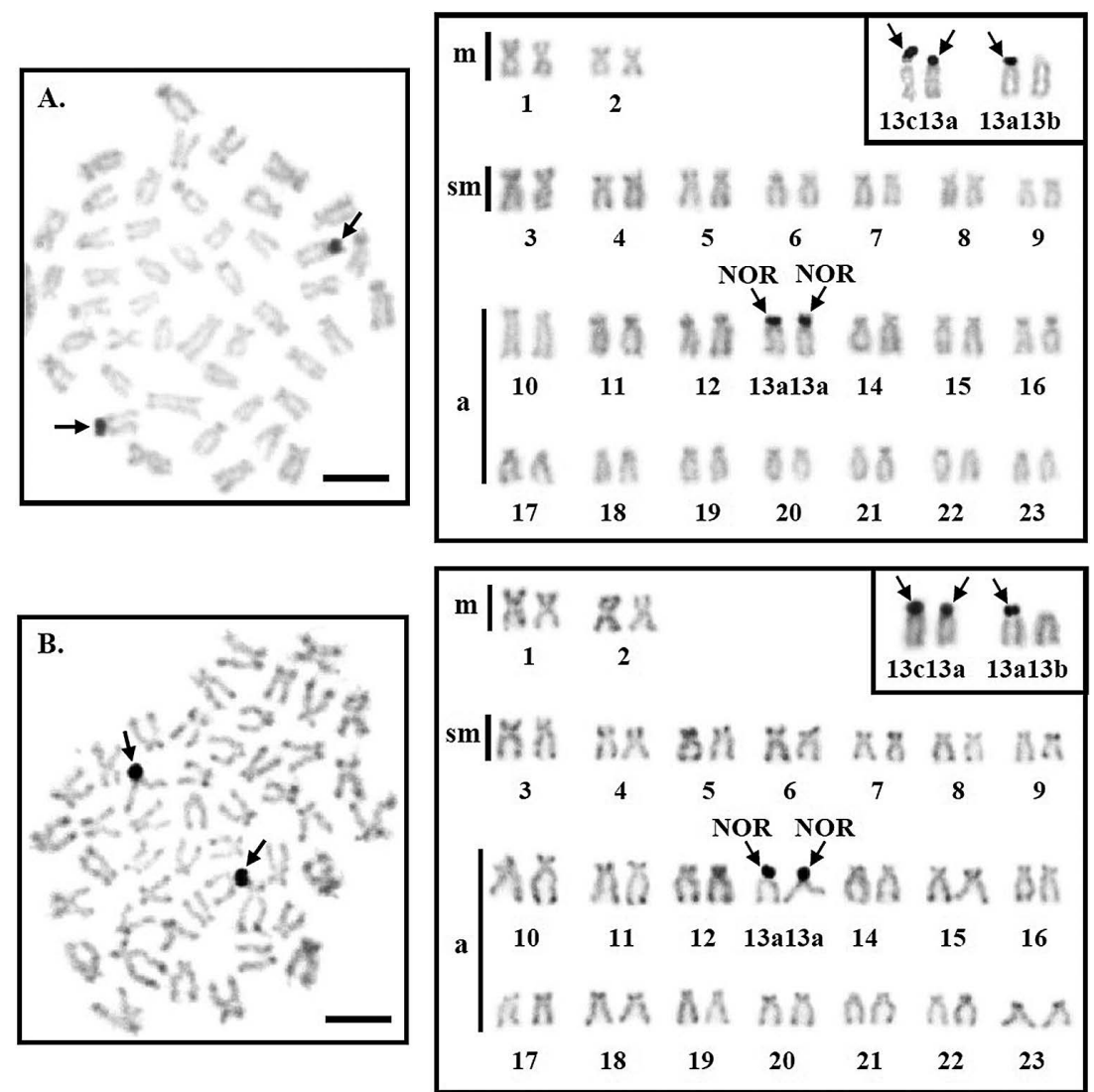

Fig. 3. Metaphase chromosome plates and karyotypes of the Banggai cardinalfish (Pterapogon kauderni) male (A) and female (B), $2 n$ (diploid) $=46$ by Ag-NOR banding technique. Arrows show three polymorphism patterns of nucleolar organizer regions (NORs) of chromosome pair 13 (13a13a, 13c13a, and 13a13b). Scale bars indicate $5 \mu \mathrm{m}$.

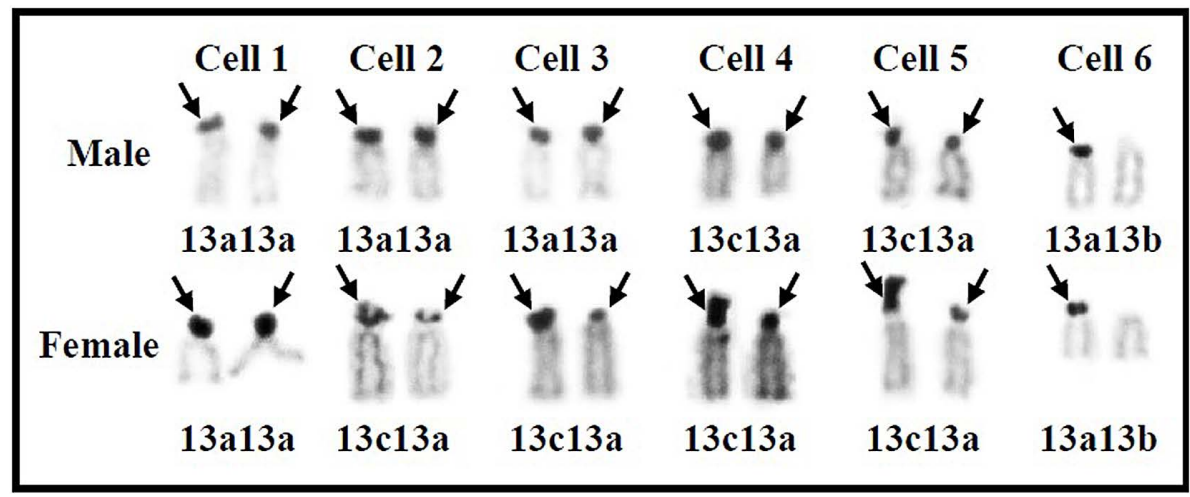

Fig. 4. The six representative cells displaying polymorphism in size of nucleolar organizer regions (NORs) of chromosome pair 13 (13a, 13b, and 13c) of the 10 male and female Banggai cardinalfish (Pterapogon kauderni). Arrows indicate nucleolar organizer regions.

in some species, a remarkable variation in the karyotype formulae is also found. Such reduction in the diploid number might be as low as $2 n=34$, as reported in $A$. maculatus (Rivlin et al. 1988). Nevertheless, the chromosomal numbers are reduced, suggesting a high incidence of centric fusions, and high fundamental numbers (NF) are also reported, like in $A$. nubilus $(2 n=46, \mathrm{NF}=92)$, which indicates that other rearrangements, such as pericentric inversions, have also played a major role in the chromosomal diversification of this fish group.

The chromosome information of the family Apogo- nidae revealed that $62.5 \%$ of all species analyzed so far $(N=16 \mathrm{spp}$.) present diploid values equal to $2 n=46$, suggesting this should be an ancestor condition for this family. Among them, the species $A$. endekataenia and $A$. moluccensis are characterized by a karyotype exclusively composed of telocentric chromosomes (Rishi 1973), a symplesiomorphic cytogenetic feature widely observed within the order Perciformes (Molina 2006). Accordingly, the available data indicates a great karyotypic diversity in the evolution of the group regarding both diploid number and chromosomal formulas, resulting 
in high fundamental numbers $(\mathrm{NF}=46-92)$. This scenario indicates a simultaneous occurrence of different mechanisms of karyotypic diversification in the family Apogonidae, mainly Robertsonian rearrangements and pericentric inversions (Araújo et al. 2010). The karyotype formula for P. kauderni is as follows:

$$
2 n \text { (diploid) } 46=\mathrm{L}_{6}^{\mathrm{a}}+\mathrm{M}_{4}^{\mathrm{m}}+\mathrm{M}_{14}^{\mathrm{sm}}+\mathrm{M}_{22}^{\mathrm{a}}
$$

\section{Chromosome markers of $\mathrm{P}$. kauderni}

This is the first report on P. kauderni accomplished by Ag-NOR banding technique. The technique show dark bands (NOR-position) on the short arm subtelomeric of acrocentric chromosome pair 13 in both males and females (Figs. 3, 4). For other comparative studies, the species in the family Apogonidae, A. americanus, had a NOR on the short arm subtelomeric of submetacentric chromosome pair 8 (Araújo et al. 2010).

Our obtained results indicated that the short arm subtelomeric of the acrocentric chromosome pair 13 showed clearly observable NORs in all of 20 examined fish (10 male and 10 female fish). It was found that the respective NOR polymorphism patterns were detected in three, six and one of both male and female fish. Three karyotypic patterns of this fish are described below: 1) homomorphic which shows an equal size of both chromosome pair 13 (13a13a), 2) heteromorphic that displays different sizes of NORs of chromosome pair 13 (13a13c) and 3) heteromorphic which is found in only one homologous chromosome pair 13 (13a13b). This is in agreement with several previous reports on Moenkhausia sanctaefilomenae (Foresti et al. 1989), Aphanius fasciatus (Vitturi et al. 1995), Leporinus friderici (Galetti et al. 1995), Salmo trutta (Castro et al. 1996), Salvelinus alpines (Reed and Phillips 1997), Chondrostoma lusitanicum (Collares-Pereira and Ráb 1999), Hoplias malabaricus (Born and Bertollo 2000), Oedalechilus labeo (Rossi et al. 2000), Astyanax scabripinnis (Soza et al. 2001), A. altiparanae (Mantovani et al. 2005), Bryconamericus aff. exodon (Paintner-Marques et al. 2002), Apareiodon affinis (Jorge and Filho 2004), Aphanius fasciatus (Vitturi et al. 2005), Prochilodus lineatus (Gras et al. 2007), B. aff. iheringii (Capistano et al. 2008), Puntioplites proctozysron (Supiwong et al. 2012), and Lutjanus johnii (Phimphan et al. 2013).

NORs play an important role in the display of perfect markers to display chromosomal polymorphism within and between species in many groups of fish. This variety may affect the NOR number, its localization on the chromosome, size, and active numbers in each genome. The previous studies of NOR exhibited variations between species, within species, and even between individuals (Castro et al. 1996). NORs on different homologous chromosomes may have different sizes. Some fish may even indicate a difference of up to a factor of two in size between NORs found on the same homologous chromo-

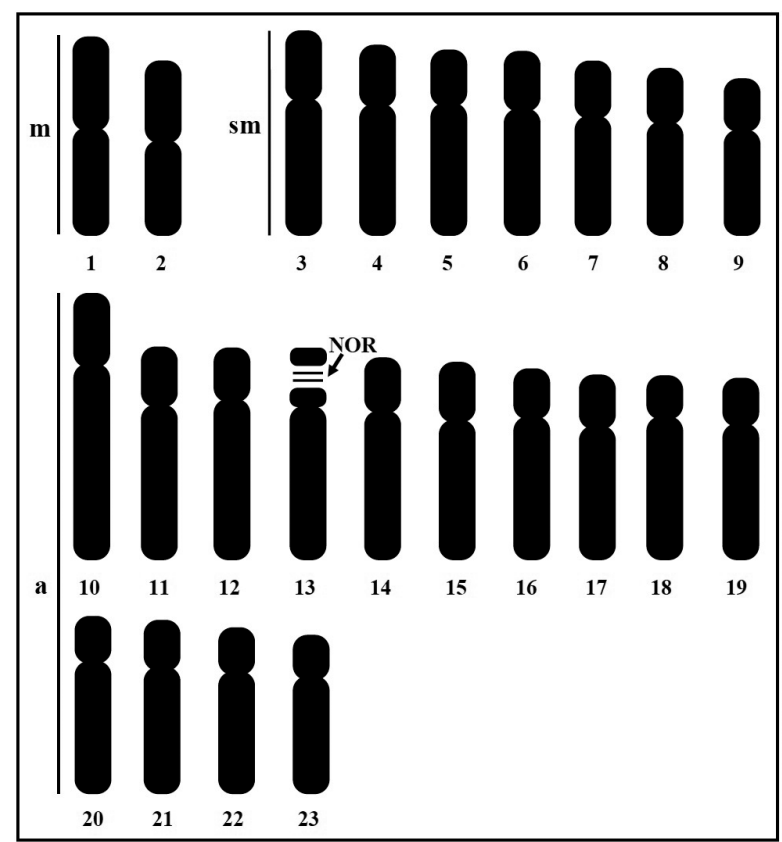

Fig. 5. Idiogram showing lengths and shapes of chromosomes of the Banggai cardinalfish (Pterapogon kauderni), diploid $(2 n)=46$, by conventional staining technique. Arrow indicates nucleolar organizer region (NOR).

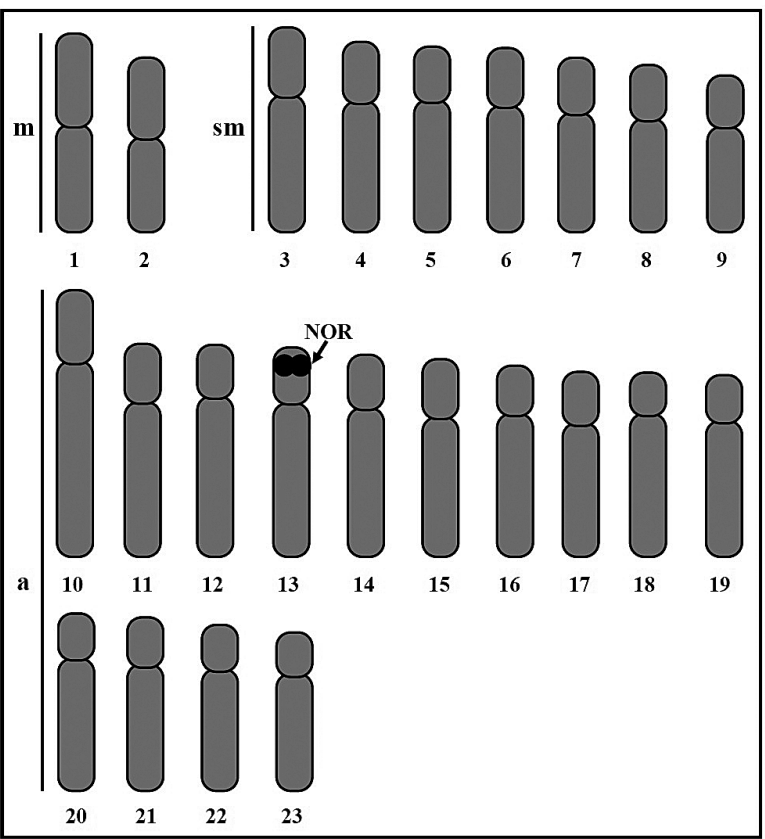

Fig. 6. Idiogram showing lengths and shapes of chromosomes of the Banggai cardinalfish (Pterapogon kauderni), diploid $(2 n)=46$, by Ag-NOR banding technique. Arrow indicates nucleolar organizer region (NOR).

some. This is in accordance with previous reports that this extent of variety between NORs may be attributed to the number of cistrons and differences in transcriptional activity (Galetti et al. 1984).

In a view of both macro and microevolutionary points, NORs are very dynamic regions in evolutionary terms. These regions have been frequently used as phylogenetic 
Table 2. Mean length of short arm chromosome (Ls), length long arm chromosome (Ll), length total arm chromosome (LT), relative length (RL), centromeric index (CI) and standard deviation (SD) of RL, CI from 20 metaphase cells of the male and female Banggai cardinalfish (Pterapogon kauderni), $2 n=46$.

\begin{tabular}{|c|c|c|c|c|c|c|c|}
\hline Chro. pair & Ls & $\mathrm{Ll}$ & LT & $\mathrm{RL} \pm \mathrm{SD}$ & $\mathrm{CI} \pm \mathrm{SD}$ & Chro. type & Chro. size \\
\hline 1 & 0.700 & 0.801 & 1.501 & $0.0230 \pm 0.0016$ & $0.535 \pm 0.016$ & Metacentric & Medium \\
\hline 2 & 0.613 & 0.705 & 1.318 & $0.0201 \pm 0.0015$ & $0.535 \pm 0.033$ & Metacentric & Medium \\
\hline 3 & 0.523 & 1.022 & 1.545 & $0.0235 \pm 0.0015$ & $0.660 \pm 0.030$ & Submetacentric & Medium \\
\hline 4 & 0.465 & 0.974 & 1.439 & $0.0219 \pm 0.0008$ & $0.674 \pm 0.032$ & Submetacentric & Medium \\
\hline 5 & 0.422 & 0.982 & 1.404 & $0.0214 \pm 0.0005$ & $0.696 \pm 0.038$ & Submetacentric & Medium \\
\hline 6 & 0.450 & 0.939 & 1.389 & $0.0212 \pm 0.0006$ & $0.675 \pm 0.036$ & Submetacentric & Medium \\
\hline 7 & 0.423 & 0.891 & 1.315 & $0.0200 \pm 0.0007$ & $0.675 \pm 0.048$ & Submetacentric & Medium \\
\hline 8 & 0.418 & 0.842 & 1.261 & $0.0192 \pm 0.0008$ & $0.667 \pm 0.022$ & Submetacentric & Medium \\
\hline 9 & 0.392 & 0.787 & 1.179 & $0.0180 \pm 0.0010$ & $0.667 \pm 0.032$ & Submetacentric & Medium \\
\hline 10 & 0.548 & 1.456 & 2.004 & $0.0306 \pm 0.0020$ & $0.724 \pm 0.024$ & Acrocentric & Large \\
\hline 11 & 0.448 & 1.147 & 1.596 & $0.0243 \pm 0.0013$ & $0.715 \pm 0.020$ & Acrocentric & Large \\
\hline 12 & 0.402 & 1.191 & 1.594 & $0.0244 \pm 0.0010$ & $0.745 \pm 0.055$ & Acrocentric & Large \\
\hline $13 *$ & 0.442 & 1.142 & 1.584 & $0.0241 \pm 0.0026$ & $0.722 \pm 0.030$ & Acrocentric & Medium \\
\hline 14 & 0.414 & 1.102 & 1.516 & $0.0231 \pm 0.0007$ & $0.725 \pm 0.034$ & Acrocentric & Medium \\
\hline 15 & 0.442 & 1.037 & 1.479 & $0.0226 \pm 0.0007$ & $0.700 \pm 0.034$ & Acrocentric & Medium \\
\hline 16 & 0.371 & 1.064 & 1.435 & $0.0219 \pm 0.0007$ & $0.740 \pm 0.047$ & Acrocentric & Medium \\
\hline 17 & 0.400 & 0.993 & 1.394 & $0.0213 \pm 0.0009$ & $0.711 \pm 0.030$ & Acrocentric & Medium \\
\hline 18 & 0.315 & 1.067 & 1.382 & $0.0211 \pm 0.0008$ & $0.770 \pm 0.036$ & Acrocentric & Medium \\
\hline 19 & 0.363 & 1.008 & 1.371 & $0.0208 \pm 0.0006$ & $0.732 \pm 0.033$ & Acrocentric & Medium \\
\hline 20 & 0.350 & 0.987 & 1.338 & $0.0203 \pm 0.0005$ & $0.737 \pm 0.040$ & Acrocentric & Medium \\
\hline 21 & 0.372 & 0.939 & 1.311 & $0.0200 \pm 0.0005$ & $0.713 \pm 0.039$ & Acrocentric & Medium \\
\hline 22 & 0.348 & 0.905 & 1.253 & $0.0190 \pm 0.0011$ & $0.719 \pm 0.022$ & Acrocentric & Medium \\
\hline 23 & 0.331 & 0.872 & 1.204 & $0.0183 \pm 0.0009$ & $0.726 \pm 0.035$ & Acrocentric & Medium \\
\hline
\end{tabular}

Remarks: *NOR-bearing chromosome and chro. $=$ chromosome.

markers (Amemiya and Gold 1988), and consequently led to differences in chromosome location being detected even between sibling species (Volleth 1987). These changes in position during evolution have been quite often attributed to chromosome rearrangements (Hall and Parker 1995). In another way, conventional cytogenetic and the most recent hybridization techniques have shown NOR regions to be also polymorphic both in number and location within species (Schmid et al. 1995). Although one NOR-bearing chromosome pair is usually considered plesiomorphic in most groups analyzed, some vertebrate species show a multichromosomal location of NORs (Suzuki et al. 1990). A constant number of several stable NOR sites has been usually observed in these species, but in some cases, the multichromosomal pattern appears to be unstable (Castro et al. 2000).

The asymmetrical karyotype of $P$. kauderni with three type of chromosomes (metacentric, submetacentric, and acrocentric chromosomes) found in this study is the important chromosome marker. The idiogram shows continuous length gradation chromosomes (Figs. $5,6)$. The size difference between the largest and the smallest chromosomes is approximately twofold. The chromosome marker of $P$. kauderni, chromosome pair 10 , is the largest acrocentric chromosome. Data of the chromosomal checks on mitotic metaphase cells of the P. kauderni are shown in Table 2 .

\section{Acknowledgements}

This work was supported by the doctoral thesis support grant from the Faculty of Science, Burapha University, fiscal year 2015 and Institute of Marine Science, Burapha University.

\section{References}

Alvarez, M. C., Otis, J., Amores, A. and Guise, K. 1991. Short-term cell culture technique for obtaining chromosomes in marine and freshwater fish. J. Fish Biol. 39: 817-824.

Amemiya, C. T. and Gold, J. R. 1988. Chromosomal NORs as taxonomic and systematic characters in North American cyprinid fishes. Genetica 76: 81-90.

Andraszek, K., Horoszewicz, E. and Smalec, E. 2009. Nucleolar organizer regions, satellite associations and nucleoli of goat cells (Capra hircus). Arch. Tierz. 52: 177-186.

Araújo, W. C., Martínez, P. A. and Molina, W. F. 2010. Mapping of ribosomal DNA by FISH, EcoRL digestion and replication bands in the cardinalfish Apogon americanus (Perciformes). Cytologia 75: 109-117.

Born, G. G. and Bertollo, L. A. C. 2000. An XX/XY sex chromosome system in a fish species, Hoplias malabaricus, with a polymorphic NOR-bearing X chromosome. Chromosome Res. 8: $111-118$.

Capistano, T. G., Portela Castro, A. L. B. and Julio-Junior, H. F. 2008. Chromosome divergence and NOR polymorphism in Bryconamericus aff. iheringii (Teleostei, Characidae) in the hydrographic systems of the Paranapanema and lvaí river, Paraná, Brazil. Genet. Mol. Biol. 31: 203-207.

Castro, J., Rodríguez, S., Pardo, B. G., Sánchez, L. and Martínez, P. 2000. Population analysis of an unusual NOR site polymorphism in brow trout (Salmo trutta L.). Heredity 86: 291-302.

Castro, J., Viñas, A., Sánchez, L. and Martínez, P. 1996. Characterization of an atypical NOR site polymorphism in brown trout (Salmo trutta) with Ag- and CMA3-staining, and fluorescent in situ hybridization. Cytogenet. Cell Genet. 75: 234-239. 
Chooseangjaew, S., Tanyaros, S., Maneechot, N., Buasriyot, P., Getlekha, N. and Tanomtong, A. 2017. Chromosomal characteristics of the tropical oyster, Crassostrea belcheri Sowerby, 1871 (Ostreoida, Ostreidae) by conventional and Ag-NOR banding techniques. Cytologia 82: 3-8.

Collares-Pereira, M. J. and Ráb, P. 1999. NOR polymorphism in the Iberian species Chondrostoma lusitanicum (Pisces: Cyprinidae) re-examination by FISH. Genetica 105: 301-303.

Foresti, F., Almeida-Toledo, L. F. and Toledo, S. A. 1989. Supernumerary chromosome system, C-banding pattern characterization and multiple nucleolus organizer regions in Moenkhausia sanctaefilomenae (Pisces, Characidae). Genetica 79: 107-114.

Galetti, P. M. Jr. 1998. Chromosome diversity in neotropical fish. NOR studies. Ital. J. Zool. (Modena) 65 (Suppl.): 53-56.

Galetti, P. M. Jr., Foresti, F., Bertollo, L. A. C. and Moreira-Filho, O. 1984. Characterization of eight species of Anostomidae (Cypriniformes) fish on the basis of the nucleolar organizing region. Caryologia 4: 401-406.

Galetti, P. M. Jr., Mestriner, C. A., Monaco, P. J. and Rasch, E. M. 1995. Post-zygotic modifications and intra- and interindividual nucleolar organizing region variation in fish: Report of a case involving Leporinus friderici. Chromosome Res. 3: 285-290.

Gras, D. E., Brassesco, M. S., Markariani, R., Roncati, H. A., Sakamoto-Hojo, E. T., Fenocchio, A. S. and Pastori, N. C. 2007. Cytogenetic polymorphism in Prochilodus lineatus (Pisces: Characiformes) from the middle Paraná River Santa Fe City, Argentina. Comp. Cytogenet. 1: 113-119.

Hall, K. J. and Parker, J. S. 1995. Stable chromosome fission associated with rDNA mobility. Chromosome Res. 3: 417-422.

Howell, W. M. and Black, D. A. 1980. Controlled silver-staining of nucleolus organizer regions with a protective colloidal developer: A 1-step method. Experientia 36: 1014-1015.

Johnson, G. D. and Gill, A. C. 1998. Encyclopedia of Fishes. Academic Press, San Diego. p. 183.

Jorge, L. C. and Filho, O. M. 2004. Nucleolar organizer region as markers of chromosomal polymorphism in Apareiodon affinis (Pisces, Parodontidae). Caryologia 57: 195-199.

Kasiroek, W., Indananda, C., Luangoon, N., Pinthong, K., Supiwong, W. and Tanomtong, A. 2017. First chromosome analysis of the humpback cardinalfish, Fibramia lateralis (Perciformes, Apogonidae). Cytologia 82: 9-15.

Mantovani, M., Able, L. D. S. and Moreira-Filho, O. 2005. Conserved $5 \mathrm{~S}$ and variable $45 \mathrm{~S}$ rDNA chromosomal localization revealed by FISH in Astyanax scabripinnis (Pisces, Characidae). Genetica 123: $211-216$.

Molina, W. F. 2006. Chromosomal changes and stasis in marine fish groups. In: Pisano, E., Ozouf-Costaz, C., Foresti, F. and Kapoor, B. G. (eds.). Fish Cytogenetics. Science Publishers, Enfield. pp. 69-110.

Murofushi, M. 1986. A study of karyotype classification and karyotype evolution in marine teleosts. Rep. Mishima Res. Inst. Sci. Liv. Nihon University 9: 95-157.

Murofushi, M., Oishi, M. and Nawa, N. 1980. Karyological studies in Apogon semilineatus. Rep. Mishima Res. Inst. Sci. Liv. Nihon University 3: 47-50.

Nanda, I., Schsrtl, M., Fiechtinger, W., Schlupp, I., Parzefall, J. and Schmid, M. 1995. Chromosomal evidence for laboratory synthesis of triploid hybrid between the gynogenetic teleost Poecilia Formosa and its host species. J. Fish Biol. 47: 619-623.

Nelson, J. S. 2006. Fishes of the World, 4th ed. John Wiley \& Sons, New York.

Ojima, Y. and Kojima, T. 1985. Chromosomal polymorphisms in Apogonidae fishes. Proc. Jpn. Acad., Ser. B, Phys. Biol. Sci. 61: 79-82.
Paintner-Marques, T. R., Giuliano-Caetano, L. and Dias, A. L. 2002. Multiple NORs in Bryconamericus aff. exodon (Osteichthyes, Characidae, Teuagonopterinae). Hereditas 137: 107-112.

Phimphan, S., Tanomtong, A., Jumrusthanasan, S., Supiwong, W., Siripiyasing, P. and Sanoamuang, L. 2013. First report of NORs polymorphism and chromosome analysis of John's snapper, Lutjanus johnii (Perciformes, Lutjanidae) in Thailand. Cytologia 78: 335-344.

Reed, M. K. and Phillips, R. B. 1997. Polymorphism of the nucleolus organizer region (NOR) on the putative sex chromosomes of Arctic char (Salvelinus alpines) is not sex related. Chromosome Res. 5: 221-227.

Rishi, K. K. 1973. A preliminary report on the karyotypes of eighteen marine fishes. Res. Bull. Punjab University 24: 161-162.

Rivlin, K. A., Dale, G. and Rachlin, J. W. 1986. Karyotypic analysis of three species of cardinalfish (Apogonidae) and its implications for the taxonomic status of the genera Apogon and Phaeoptyx. Ann. N. Y. Acad. Sci. 463 (1 Second Colloq): 211-213.

Rivlin, K. A., Rachlin, J. W. and Dale, G. 1987. Intraspecific chromosomal variation in Apogon binotatus (Perciformes: Apogonidae) from the Florida Keys and St. Croix. Ann. N. Y. Acad. Sci. 494 (1 Third Colloqu): 263-265.

Rivlin, K. A., Rachlin, J. W. and Warkentine, B. E. 1988. GBanding of the chromosomes of Apogon maculatus and A. pseudomaculatus (Perciformes: Apogonidae). Ann. N. Y. Acad. Sci. 529 (1 Fourth Colloq): 160-163.

Rossi, A. R., Gornung, E., Crosetti, D., Innocentti, S. and Sola, L. 2000. Cytogenetic analysis of Oedalechilus labeo (Pisces: Muglidae), with a report of NOR variability. Mar. Biol. 136: 159-162.

Sangpakdee, W., Phimphan, S., Tengjaroenkul, B., Pinthong, K., Neeratanaphan, L. and Tanomtong, A. 2017. Cytogenetic study of tree microhylid species (Anura, Microhylidae) from Thailand. Cytologia 82: 67-74.

Schmid, M., Feichtinger, W., Weimer, R., Mais, C., Bolaños, F. and Feón, P. 1995. Chromosome banding in Amphibia. XXI. Inversion polymorphism and multiple nucleolus organizer regions in Agalychnis callidryas (Anura, Hylidae). Cytogenet. Cell Genet. 69: 18-26.

Soza, I. L., Galian, J., De La Rua, P., Bertollo, L. A. C. and MoreiraFilho, O. 2001. Non-random distribution and nucleolar rDNA sites on Astyanax scabripinnis chromosomes. Cytologia 66: 85-91.

Supiwong, W., Tanomtong, A., Supanuam, P., Jantarat, S., Khakhong, S. and Sanoamuang, S. 2012. A discovery of nucleolar organizer regions (NORs) polymorphism and karyological analysis of Smith's barb, Puntioplites proctozysron (Cypriniformes, Cyprinidae) in Thailand. Cytologia 77: 35-42.

Suzuki, H., Kurihara, Y., Kanemisha, Y. and Moriwaki, K. 1990. Variation in the distribution of silver-staining nucleolar organizer regions on the chromosomes of the wild mouse Mus musculus. Mol. Biol. Evol. 7: 271-282.

Vitturi, R., Catalano, E., Colomba, M. S., Montagnino, L. and Pellerito, L. 1995. Karyotype analysis of Aphanius fasciatus (Pisces: Cyprinodontiformes): Ag-NORs and C-band polymorphism in four populations from Sicily. Biol. Zent. B1. 114: 392-402.

Vitturi, R., Colomba, M., Vizzini, S., Libertini, A., Barbieri, R. and Mazzola, A. 2005. Chromosomal location polymorphism of major rDNA sites in two Mediterranean populations of the killifish Aphanius fasciatus (Pisces: Cyprinodontidae). Micron 36: 243-246.

Volleth, M. 1987. Differences in the location of nucleolus organizer regions in European vespertilionid bats. Cytogenet. Cell Genet. 44: 186-197. 